\title{
Study of calcium profile in neuronal cells with respect to temperature and influx due to potential activity
}

\author{
Patil J. V. ${ }^{1}$, Vaze A. N. ${ }^{2}$, Sharma L. ${ }^{2}$, Bachhav A. ${ }^{3}$ \\ ${ }^{1}$ Department of Mathematics, Vasantrao Naik Mahavidyalaya, Aurangabad, India \\ ${ }^{2}$ Department of First Year Engineering, Pimpri Chinchwad College of Engineering, Pune, India \\ ${ }^{3}$ Navin Jindal School of Management, University of Texas, Dallas, USA
}

(Received 22 October 2020; Accepted 11 April 2021)

\begin{abstract}
Calcium is a critically important second messenger in the nervous system. It enters through voltage-gated $\mathrm{Ca}^{2+}$ channels and regulates the release of the synaptic transmitter. This mechanism is monitored by calcium diffusion, buffering mechanism and calcium influx into the cytoplasm. The study of $\mathrm{Ca}^{2+}$ dynamics is interesting because the concentration of $\mathrm{Ca}^{2+}$ shows highly complex spatial-temporal behavior. There are many controls on the cytoplasmic $\mathrm{Ca}^{2+}$ concentration. First, it is heavily buffered (i.e., bound) by large proteins and second control is that of the variable diffusion coefficient. The diffusion coefficient is directly proportional to the temperature and inversely proportional to the viscosity. In this paper, the one-dimensional steady-state case with boundary conditions has been studied to understand the $\mathrm{Ca}^{2+}$ distribution in neuronal cells incorporating diffusion of calcium, point source, excess buffer approximation (EBA), an influx due to the calcium current. Moreover, the dependency of $\mathrm{Ca}^{2+}$ concentration based on the variable diffusion coefficient is studied. The finite element method (FEM) has been employed to obtain the solutions.
\end{abstract}

Keywords: calcium diffusion, variable diffusion coefficient, EBA, FEM.

2010 MSC: 92-10, 92B05, 92C20, 35A25

DOI: $10.23939 / \mathrm{mmc} 2021.02 .241$

\section{Introduction}

Calcium is an active signaling molecule in neurons and it can initiate a diverse set of actions from neurotransmitter release to every aspect of cellular life. Cellular calcium activates systematically which is monitored by several processes including localized calcium entry, binding by different buffers, distribution within neuronal compartments and removal from the intracellular space. In combination, these regulatory actions produce different spatial and temporal domains of calcium distribution in the synaptic cleft. Calcium signals are limited to small dendritic segments and global calcium elevations are involved in the entire cell $[1,2]$.

Calcium signaling is of paramount importance, so the study of $\mathrm{Ca}^{2+}$ regulatory mechanism in neurons has gained interest in the late 90s. The buffers and influxes play an important role in calcium regulation in neurons. Buffers are basically proteins that bind free calcium ions and store calcium at local sites in the form of bound calcium. They release free calcium at the sites wherever required and also contribute to the transport of calcium from one place to another through gated channels [3-8].

Calcium entry, binding, diffusion, and removal have been topics of extensive discussion to understand the role of calcium contribution to neuronal activity. Similarly, this study is essential for a better understanding of the functional consequences of calcium distribution in information propagation as well as pre-synaptic and post-synaptic activities [2]. Therefore, the diffusion of $\mathrm{Ca}^{2+}$ is a vital process for signaling in neuronal cells and neurotransmitters.

While studying the diffusion of $\mathrm{Ca}^{2+}$ in neuronal cells, we must understand the physiology of neuronal cell and cytoplasm where synaptic activity initiates, completes and propagates to the next neuron. The diffusion of calcium is a highly intricate process involving various parameters like gated channels, receptors, domains, buffers, etc. [9, 10]. In the current mathematical model, we involved 
variable diffusion coefficient along with boundary conditions and further parameters like temperature of neuronal cell and viscosity of the cytosolic fluid.

Most of the work done by earlier researchers includes the problem of diffusion of calcium in neuronal cells for one or two-dimensional steady or unsteady state cases which involves only constant diffusion coefficients $[8,11-14]$. In the present model, we study the effect of viscosity on diffusion coefficient due to temperature variation and hence effect on calcium concentration profile in cytosolic plasma. Although it is possible to study each of these components separately, the results can be obtained easily but it will not be much meaningful. If all of these components are included then it will be difficult to get meaningful data. To overcome this problem, a mathematical model including variable temperature and a diffusion coefficient is studied. The finite element approach is developed to map variation in calcium concentration with respect to distance $[15,16]$.

The first part of the current study includes numerical results based on cytoplasmic viscosity depending on temperature and hence its effect on the diffusion coefficient. In the second part, the model of excess buffering approximation in presence of influx due to potential activity in steady state condition is developed for the diffusion of calcium in neurons. The model developed in this paper is for one-dimensional steady state condition using the finite element method $[15,17,18]$.

\section{Biological background}

\subsection{Anatomy of cytoplasm and functioning in signal transduction}

Cytoplasm refers to the fluid that fills the cell, which includes the cytosol along with filaments, proteins, ions and macro-molecular structures as well as the organelles suspended in the cytosol. In eukaryotic cells, cytoplasm refers to the contents of the cell except for the nucleus. Active transport is involved in the creation of these sub-cellular structures and for maintaining homeostasis with the cytoplasm.

The cytoplasm is unusual because it is unlike any other fluid found in the physical world. Liquids that are studied to understand diffusion usually contains a few solutes in an aqueous environment. However, the cytoplasm is a complex and crowded system containing a wide range of particles - from ions and small molecules to proteins as well as giant multi-protein complexes and organelles. These constituents are moved across the cell depending on the requirements of the cell along an elaborate cytoskeleton with the help of specialized motor proteins. The movement of such large particles also changes the physical properties of the cytosol $[9,19]$.

The cytoplasm is the place where this diffusion is carried out. Depending on the type of cell, cytoplasm may include various compositions and organizations. However, the liquid aqueous phase is invariably present in all cells. It provides a medium in which a significant number of metabolic activities and signaling take place [20,21]. Viscosity along with the water activity, acidity and ionic strength is one of the fundamental parameters of the aqueous medium which defines the conditions of the physicochemical processes therein. Viscosity is defined as friction in fluids and it is responsible for the resistance to the movement of one part against another [21]. Various studies show that viscosity is a temperature-dependent function [22], the dynamic viscosity can be estimated using the semi-empirical Vogel-Fulcher-Tammann equation which is:

$$
\eta=\eta_{0} \exp \left(\frac{B}{T-T_{V F}}\right)
$$

where, $\eta_{0}$ and $B$ are empirical material dependent parameter and $T_{V F}$ is an empirical fitting parameter. These three parameters are normally used as adjustable parameters to fit the VFT equation to experimental data of specific systems [23]. The liquid aqueous phase of the cytoplasm contains almost $80 \%$ of water and $20 \%$ of other components [21]. Therefore, the viscosity of water can be determined for the determination of cytocolic friction and diffusion coefficient which are responsible for calcium signaling. 


\subsection{Effect of temperature on neuronal functioning}

Temperature is also an important influencer of neuronal function and synaptic signaling. Change in temperature can affect neuronal physiology in various ways depending on how it affects different members of the cells ion channel, the viscosity of cytoplasm and hence diffusion coefficient [24,25]. For this paper, we are mainly focussing on variation in the diffusion coefficient due to different values of temperature. Recently, the importance of the effect of temperature in cell functioning has been highlighted as it correlates with biochemical reaction rates $[24,25]$. For this paper, we have considered homogeneous cell homeostasis with variation in temperature from $25^{\circ} \mathrm{C}$ to $37^{\circ} \mathrm{C}$. Variation of temperature is considered to evaluate the viscosity of the cytosolic fluid as stated in equation 1. Similarly, the diffusion coefficient for Calcium signaling was calculated with the above temperature span. [Diffusion coefficient depending on temperature is discussed in a subsequent section 4.]

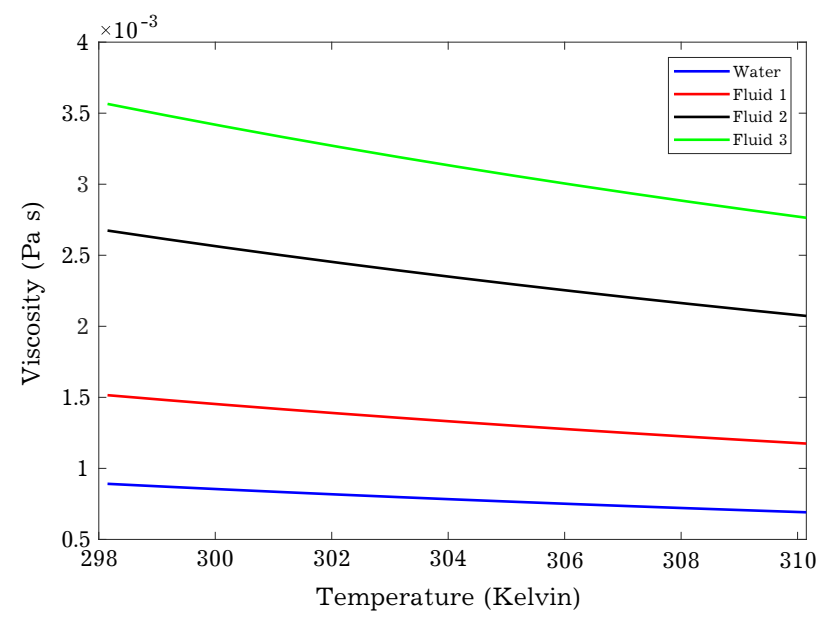

Fig. 1. Graph of viscosity versus temperature in the cytoplasm. Behavior of viscosity against water [blue line] is studied with the VFT equation. Similarly, fluid 1 [1.7 times more viscous than water, red line], fluid 2 [3 times more viscous than water, black line] and fluid 3 [4 times more viscous than water, green line] are taken to study viscosity against temperature. In this paper cytoplasm is cosidered as fluid 3 .

We consider $\eta_{0}=0.02939 \mathrm{mPas}, B=507.88 \mathrm{~K}$ and $T_{V F}=149.3 \mathrm{~K}$. Experimentally determined values of the viscosity can be evaluated at different values of temperatures. Figure 1 shows the variation of viscosity for fluids which are more viscous than water. These numerical values are used to calculate diffusion coefficient.

\section{Mathematical background}

In the cytoplasm of neurons, calcium follows mass action reaction which is represented by the reactiondiffusion equations $[3,4,8,26,27]$. This assumes a bimolecular association reaction between calcium and buffer as:

$$
\mathrm{Ca}^{2+}+\mathrm{B} \underset{k-}{\stackrel{k+}{\rightleftarrows}} \mathrm{CaB} \text {. }
$$

Here, $\mathrm{B}$ represents free buffer, $\mathrm{CaB}$ represent $\mathrm{Ca}^{2+}$-bound buffer, $k^{+}$and $k^{-}$are association and dissociation rate constants respectively. If we further assume that the reaction of $\mathrm{Ca}^{2+}$ with buffer follows mass-action kinetics, we can write the following system of ODEs [8, 12]; for the change in concentration of each species.

$$
\begin{aligned}
\frac{\partial\left[\mathrm{Ca}^{2+}\right]}{\partial t} & =D_{\mathrm{Ca}} \nabla^{2}\left[\mathrm{Ca}^{2+}\right]+\sum_{j} R_{j}+\sum J, \\
\frac{\partial\left[\mathrm{B}_{j}\right]}{\partial t} & =D_{\mathrm{B}_{j}} \nabla^{2} \mathrm{~B}_{j}+R_{j}, \\
\frac{\partial\left[\mathrm{CaB}_{j}\right]}{\partial t} & =D_{\mathrm{CaB}_{j}} \nabla^{2}\left[\mathrm{CaB}_{j}\right]-R_{j},
\end{aligned}
$$

where the reaction terms, $R_{\mathrm{j}}$, are given by

$$
R_{j}=-k_{j}{ }^{+}\left[\mathrm{Ca}^{2+}\right]\left[\mathrm{B}_{j}\right]+k_{j}^{-}\left[\mathrm{CaB}_{j}\right] .
$$

$j$ is an index over $\mathrm{Ca}^{2+}$ buffers, $D_{\mathrm{Ca}}, D_{\mathrm{B}_{j}}, D_{\mathrm{CaB} j}$ are diffusion coefficients of free $\mathrm{Ca}^{2+}$, free buffer and bound buffer respectively. 


\subsection{Diffusion of calcium in presence of excess buffer}

Intracellular $\mathrm{Ca}^{2+}$ signaling is governed by diffusion and buffering of $\mathrm{Ca}^{2+}$. Mobile endogenous buffers increase the redistribution of $\mathrm{Ca}^{2+}$ and tend to restrict the regions of elevated $\mathrm{Ca}^{2+}$ concentrations to the close vicinity of the channel. These $\mathrm{Ca}^{2+}$ microdomains dominate fast calcium signaling, as observed, e.g., in synaptic transmission. The steady-state solution of the linearized differential equations of buffered $\mathrm{Ca}^{2+}$ diffusion, as developed by Neher [12], will be reviewed and generalized by using a different technique of mathematical solution. We know that the association and dissociation rate constants for the bimolecular association reaction between $\mathrm{Ca}^{2+}$ and buffer $j$ can be combined to obtain a dissociation constant $K_{j}$,

$$
K_{j}=k_{j}^{-} / k_{j}^{+} .
$$

Let $\left[\mathrm{Ca}^{2+}\right]_{\infty}$ be background or ambient free $\mathrm{Ca}^{2+}$ concentration, and $[\mathrm{B}]_{\infty}$ and $[\mathrm{CaB}]_{\infty}$ be the equilibrium concentrations of free and bound buffer. Diffusion constant of each mobile buffer is not affected by the binding of $\mathrm{Ca}^{2+}$ and for stationary buffers $D_{\mathrm{B}_{j}}, D_{\mathrm{CaB}_{j}}$ are zero. Here, higher values for $K$ imply that the buffer has a lower affinity for $\mathrm{Ca}^{2+}$ and is less easily saturated. In this case, the equations for the buffered diffusion of $\mathrm{Ca}^{2+}$ for single buffer become.

$$
\frac{\partial\left[\mathrm{Ca}^{2+}\right]}{\partial t}=D_{\mathrm{c}} \nabla^{2}\left[\mathrm{Ca}^{2+}\right]-k^{+}[B]_{\infty}\left(\left[\mathrm{Ca}^{2+}\right]-\left[\mathrm{Ca}^{2+}\right]_{\infty}\right)+J
$$

For numerical simulations, a reasonable initial condition of uniform 'background'of $\mathrm{Ca}^{2+}$ profile is considered. We further assumed that all buffers are initially in equilibrium with $\mathrm{Ca}^{2+}$ and required far from the source to remain in equilibrium with $\mathrm{Ca}^{2+}$ at all times.

$$
\lim _{r \rightarrow \infty}\left[\mathrm{Ca}^{2+}\right]=\left[\mathrm{Ca}^{2+}\right]_{\infty} \quad \text { and } \quad \lim _{r \rightarrow \infty}\left[\mathrm{B}_{j}\right]=\left[\mathrm{B}_{j}\right]_{\infty}
$$

Near the source, we enforce the boundary conditions

$$
\lim _{r \rightarrow 0}\left[4 \pi D_{c} r^{2} \frac{\partial\left[\mathrm{Ca}^{2+}\right]}{\partial r}\right]=\sigma,
$$

and

$$
\lim _{r \rightarrow \infty}\left[4 \pi D_{c} r^{2} \frac{\partial\left[\mathrm{B}_{j}\right]}{\partial r}\right]=0
$$

\subsection{Influx due to $\mathrm{Ca}^{2+}$ current in response to potential activity}

The Goldmann-Hodgkin-Katz equation [9] given by:

$$
I_{C a}=P_{\max } V z F\left[\frac{\left[\mathrm{Ca}^{2+}\right]_{\infty}-\left[\mathrm{Ca}^{2+}\right] e^{\varepsilon V}}{1-e^{\varepsilon V}}\right]
$$

where, $\varepsilon=0.0778491 \mathrm{mV}^{-1}, P_{\max }=5.4 \times 10^{-6} \mathrm{~m} / \mathrm{s}, V$ is the membrane/resting potential, $z$ is the valence of Calcium and $\left[\mathrm{Ca}^{2+}\right]_{\infty}$ is the extracellular concentration. Thus, influx due to calcium current is calculated by

$$
J_{\mathrm{Ca}}=\frac{-I_{\mathrm{Ca}}}{z F} .
$$

In the excess buffer approximation (EBA), equation 6 is simplified by assuming that the concentration of free buffer $\mathrm{B}_{j}$ concentration, is high enough that its loss is negligible. The EBA gets its name because this assumption of the unsaturability of $\mathrm{Ca}^{2+}$ buffer is likely to be valid when $\mathrm{Ca}^{2+}$ buffer is in excess i.e., $\left[\mathrm{B}_{j}\right]=\left[\mathrm{B}_{j}\right]_{\infty}$. 
A finite element model has been developed for the diffusion of $\mathrm{Ca}^{2+}$ in the presence of excess buffer approximation in neurons. This model incorporates the effect of potential activity-dependent influx on calcium diffusion process. The parameters like diffusion rate, dissociation rate, conductance and membrane potential are incorporated in the above model. Appropriate boundary conditions have been framed using physical processes involved in influx. The finite element method have been employed to obtain a numerical solution to the problem. The relationships among various parameters have been studied. The concentration profiles have been obtained w.r.t. position and temperature. From equation (6), (8), (11) and (12) we obtain

$$
\frac{\partial\left[\mathrm{Ca}^{2+}\right]}{\partial t}=D_{\mathrm{c}} \nabla^{2}\left[\mathrm{Ca}^{2+}\right]-k^{+}[\mathrm{B}]_{\infty}\left(\left[\mathrm{Ca}^{2+}\right]-\left[\mathrm{Ca}^{2+}\right]_{\infty}\right)-P_{\max } V \varepsilon\left[\frac{\left[\mathrm{Ca}^{2+}\right]_{\infty}-\left[\mathrm{Ca}^{2+}\right] e^{\varepsilon V}}{1-e^{\varepsilon V}}\right] .
$$

\section{Diffusion coefficient as a function of viscosity and temperature}

The diffusion coefficient for calcium can be a variable quantity which is based on the Boltzmann constant $(k)$, frictional coefficient $(f)$ and absolute temperature of calcium molecule $(T)$ as

$$
D=\frac{k T}{f}
$$

Fluid friction is the force that resists motion within the fluid itself. $f$ represents the frictional coefficient which depends upon size, shape and viscosity of the molecule [here, calcium molecule]. The friction coefficient is calculated as: $f=6 \pi \eta R$, where $R$ is the radius of the calcium atom. Atomic radii are not precisely defined but are nevertheless widely used parameters in modeling and understanding molecular structure and interactions. The Van-der-Waals radii determined by Bondi from molecular crystals are the most widely used values. The Radius of the calcium molecule required for viscosity determination is calculated as $231 \times 10^{-12} \mathrm{pm}$ [28]. The cytoplasm is mainly composed of water, considering dynamic viscosity of water at different temperatures, the diffusion coefficient $D$ is calculated for calcium [denoted by $D_{c}$ for this paper] [20,21]. Many researchers considered constant value of diffusion coefficient to determine calcium diffusion in neuronal cell $[6,8,12-14,27]$. In this paper, we calculated the diffusion coefficient for different values of viscosity and temperature. We observed numerical value for the diffusion coefficient as $D_{c}=265 \mu \mathrm{m}^{2} / \mathrm{s}$ at temperature $25^{\circ} \mathrm{C}$ for cytoplasm [Here, cytoplasm is fluid 3, which is 4 times more viscous than water]. This value is near to the constant value of the diffusion coefficient used by earlier researchers. So, we have concluded that in all research regarding calcium diffusion, cytosolic fluid was considered to be four times more viscous than water. Therefore, the diffusion coefficient with value $D_{c}=265 \mu \mathrm{m}^{2} / \mathrm{s}$ is considered hereafter for further numerical simulations.

\section{Finite element model}

To obtain the solution of equation (13) we use the transformation, $u=\left[\mathrm{Ca}^{2+}\right]$. Therefore, we get

$$
\begin{aligned}
\frac{\partial u}{\partial t} & =D_{\mathrm{c}} \nabla^{2} u-k^{+}[\mathrm{B}]_{\infty}\left[u-u_{\infty}\right]+\left(-\frac{\varepsilon P_{\max } V}{\left(1-e^{\varepsilon V}\right)}\right)\left[u_{\infty}-u e^{\varepsilon V}\right] \\
& =D_{\mathrm{c}} \nabla^{2} u-\left[k^{+}[\mathrm{B}]_{\infty}-\frac{\varepsilon P_{\max } V}{\left(1-e^{\varepsilon V}\right)}\right] u+\left[k^{+}[\mathrm{B}]_{\infty}-\frac{\varepsilon P_{\max } V}{\left(1-e^{\varepsilon V}\right)}\right] u_{\infty} .
\end{aligned}
$$

Let,

$$
a=\frac{\left[k^{+}[\mathrm{B}]_{\infty}-\frac{\varepsilon P_{\max } V}{\left(1-e^{\varepsilon V}\right)}\right]}{D_{\mathrm{c}}} \quad \text { and } \quad b=\frac{\left[k^{+}[\mathrm{B}]_{\infty}-\frac{\varepsilon P_{\max V}}{\left(1-e^{\varepsilon V}\right)}\right]}{D_{\mathrm{c}}} u_{\infty}
$$

Mathematical Modeling and Computing, Vol. 8, No. 2, pp. 241-252 (2021) 
So, equation (15) can now be abbreviated as

$$
\frac{1}{D_{C}} \frac{\partial u}{\partial t}=\nabla^{2} u-a u+b
$$

The equation (15) in spherical coordinates in one dimension for steady state condition and setting $\frac{\partial u}{\partial t}=0$ is written as

$$
\frac{\partial}{\partial r}\left(r^{2} \frac{\partial u}{\partial r}\right)-a r^{2} u+b r^{2}=0
$$

here, $u(r)=\left[\mathrm{Ca}^{2+}\right]$.

The study has been performed in spherical symmetric region $1 \leqslant r \leqslant 5$. The following boundary conditions are imposed

$$
u(0)=\alpha \mu \mathrm{M}, \quad \text { and } \quad u(5)=0.1 \mu \mathrm{M} .
$$

Here, $\alpha$ is a free calcium concentration that varies with binding activity of buffers. It can be assigned the fixed value-based on standard values of free calcium concentration. At the other end $r=5 \mu \mathrm{m}$ the value of calcium concentration is constant because the profile uniformly converges to $0.1 \mu \mathrm{m}$. The variational form of equation (18) along with boundary conditions equation (19) is given by

$$
I[u(r)]=-\frac{1}{2} \int_{1}^{5}\left[r^{2}\left(\frac{\partial u}{\partial r}\right)^{2}+a r^{2} u^{2}-2 b r^{2} u\right] d r+\left.\frac{\sigma}{4 \pi D_{c}} u\right|_{r=r_{1}} .
$$

We assume that the functional $I$ can be written as the sum of elemental functional $I^{(e)}$ as

$$
I[u(r)]=\sum_{e=1}^{M} I^{(e)}
$$

where,

$$
I^{(e)}=-\frac{1}{2} \int_{r_{i}}^{r_{i+1}}\left[r^{2}\left(\frac{\partial u^{(e)}}{\partial r}\right)^{2}+a r^{2}\left[u^{(e)}\right]^{2}-2 b r^{2}\left[u^{(e)}\right]\right] d r+\left.\frac{\sigma}{4 \pi D_{c}} u^{(e)}\right|_{e=1}
$$

Here, $I^{(e)}$ represents discretized variational form of equation 18 and $r_{i}, r_{i+1}$ are the coordinates of the ends nodes of the typical element $e$. The functional $u^{(e)}$ is defined over the element $(e)$ and zero elsewhere. We take the approximate solution in the form

$$
u^{(e)}=N_{i} u_{i}+N_{i+1} u_{i+1}=N^{(e)} \phi^{(e)},
$$

where,

$$
N_{i}=\frac{r_{i+1}-r}{r_{i+1}-r_{i}} \quad \text { and } \quad N_{i+1}=\frac{r-r_{i}}{r_{i+1}-r_{i}}
$$

Therefore,

$$
N^{(e)}=\left[N_{i}, N_{i+1}\right] \quad \text { and } \quad \phi^{(e)}=\left[u_{i}, u_{i+1}\right]
$$

Substituting equations (23) to (25) into (22), we obtain

$$
\begin{aligned}
I^{(e)}= & -\frac{1}{2} \int_{r_{i}}^{r_{i+1}}\left[r^{2}\left\{\left[\begin{array}{ll}
N_{i}^{\prime} & N^{\prime}{ }_{i+1}
\end{array}\right]\left[\begin{array}{c}
u_{i} \\
u_{i+1}
\end{array}\right]\right\}^{2}+\operatorname{ar}^{2}\left\{\left[\begin{array}{ll}
N_{i} & N_{i+1}
\end{array}\right]\left[\begin{array}{c}
u_{i} \\
u_{i+1}
\end{array}\right]\right\}^{2}\right. \\
& \left.-2 b r^{2}\left\{\left[\begin{array}{ll}
N_{i} & N_{i+1}
\end{array}\right]\left[\begin{array}{c}
u_{i} \\
u_{i+1}
\end{array}\right]\right\}\right] d r+\left.\frac{\sigma}{4 \pi D_{c}} u^{(e)}\right|_{e=1} .
\end{aligned}
$$

Where prime denotes differentiation w.r.t. $r$. The conditions for extremizing $I^{e}$ w.r.t. the nodal quantities give the $u_{i}$ and $u_{i+}$ element equations for a typical element $(e)$ as $\frac{\partial I^{(e)}}{\partial u_{i}}=0$ and $\frac{\partial I^{(e)}}{\partial u_{i+1}}=0$. 
In matrix form

$$
A^{(e)} \phi^{(e)}=B^{(e)},
$$

where,

$$
A^{(e)}=\int_{r_{i}}^{r_{i+1}}\left\{r^{2}\left[\begin{array}{cc}
N^{\prime}{ }_{i} N_{i}^{\prime} & N^{\prime}{ }_{i} N_{i+1}^{\prime} \\
N^{\prime}{ }_{i+1} N^{\prime}{ }_{i} & N^{\prime}{ }_{i+1} N^{\prime}{ }_{i+1}
\end{array}\right]+a r^{2}\left[\begin{array}{cc}
N_{i} N_{i} & N_{i} N_{i+1} \\
N_{i+1} N_{i} & N_{i+1} N_{i+1}
\end{array}\right]\right\} d r
$$

and

$$
B^{(e)}=\int_{r_{i}}^{r_{i+1}}\left\{r^{2}\left[\begin{array}{c}
N_{i} \\
N_{i+1}
\end{array}\right]\right\} d r-\left.\frac{\sigma}{4 \pi D_{c}} u^{(e)}\right|_{e=1} .
$$

Summing over $e=1,2, \ldots, m$ and extremization of $e=1,2, \ldots, m$ w.r.t. the nodal points, we get

$$
A \Phi=B
$$

where $A, \phi$ and $B$ are global matrices. As a special we consider the region to be divided into four elements as $e=1,2,3,4$ and interval $r=[1,5]$ in $\mu m$. For $e=1$, we solve the equation (29), we obtain

$$
A^{(1)}=\left[\begin{array}{cc}
\frac{7}{3}+\frac{8}{15} a & -\frac{7}{3}+\frac{23}{60} a \\
-\frac{7}{3}+\frac{23}{60} a & \frac{7}{3}+\frac{31}{30} a
\end{array}\right] \quad \text { and } \quad B^{(1)}=\left[\begin{array}{c}
\frac{11}{12} b \\
\frac{17}{12} b
\end{array}\right] .
$$

Similarly, calculating for $e=2,3,4$ and summing over all elements we get equation (29) in following form

$$
\left[\begin{array}{ccccc}
\frac{7}{3}+\frac{8}{15} a & -\frac{7}{3}+\frac{23}{60} a & 0 & 0 & 0 \\
-\frac{7}{3}+\frac{23}{60} a & \frac{26}{3}+\frac{517}{60} a & \frac{-19}{3}+\frac{21}{20} a & 0 & 0 \\
0 & \frac{-19}{3}+\frac{21}{20} a & \frac{56}{3}+\frac{91}{15} a & -\frac{37}{3}+\frac{141}{60} a & 0 \\
0 & 0 & -\frac{37}{3}+\frac{41}{60} a & \frac{98}{3}+\frac{161}{15} a & -\frac{61}{3}+\frac{203}{60} a \\
0 & 0 & 0 & -\frac{61}{3}+\frac{203}{60} a & \frac{61}{3}+\frac{113}{15} a
\end{array}\right]\left[\begin{array}{c}
u_{0} \\
u_{1} \\
u_{3} \\
u_{4} \\
u_{5}
\end{array}\right]=\left[\begin{array}{c}
\frac{11}{12} \\
\frac{50}{12} \\
\frac{110}{12} \\
\frac{194}{12} \\
\frac{131}{12}
\end{array}\right] b
$$

A MATLAB program has been developed to solve equation (31) to obtain nodal values of $u$. These values of $u_{i}$ are substituted in (23) to find the value of $u^{e}$ in each element $e$.

\section{Numerical results and discussion}

The numerical values for various parameters, have been used from Tables 1, 2 and 3 to compute the numerical results. Variation in diffusion coefficient is studied for different values of temperature. Also, the effect of variable diffusion coefficient on calcium concentration has been studied. The equation (31) is solved for fixed diffusion coefficient and different endogenous buffers and exogenous buffers. All graphs have been plotted and discussed.

Table 1. Numerical values of various calcium buffers [Exogenous].

\begin{tabular}{|c|c|c|c|c|}
\hline $\mathrm{Ca}^{2+}$ buffer & $k^{+}, \mu \mathrm{M}^{-1} \mathrm{~s}^{-1}$ & $k^{-}, \mathrm{s}^{-1}$ & $K, \mu \mathrm{M}$ & {$[B]_{T}, \mu \mathrm{M}$} \\
\hline EGTA & 1.5 & 0.3 & 0.2 & 113 \\
\hline BAPTA & 600 & 100 & $0.1-0.7$ & 95 \\
\hline
\end{tabular}

Water has low viscosity and hence a high diffusion coefficient. Low viscosity and high diffusion coefficient both are important according to its role as a solvent in the physio-chemical reactions of cells. In addition, cytosolic fluid though it contains $80 \%$ of water and $20 \%$ of other parameters like proteins, ions, macromolecules etc. is more viscous compared to water. According to recent research 
Table 2. Numerical values of various calcium buffers [Endogenous].

\begin{tabular}{|c|c|c|c|c|}
\hline $\mathrm{Ca}^{2+}$ buffer & $k^{+}, \mu \mathrm{M}^{-1} \mathrm{~s}^{-1}$ & $k^{-}, \mathrm{s}^{-1}$ & $K, \mu \mathrm{M}$ & {$[\mathrm{B}]_{T}, \mu \mathrm{M}$} \\
\hline Troponin-C & $90-100$ & $7-300$ & $0.05-30$ & 50 (varied) \\
\hline Calmodulin D28K & $100-500$ & $37-470$ & $0.2-2.0$ & 32 \\
\hline Triponin C & 39 & 20 & 0.51 & 70 \\
\hline Parvalbumin & 6 & 1 & 0.00037 & 36 \\
\hline
\end{tabular}

Table 3. Values of biological parameters used.

\begin{tabular}{|c|c|c|}
\hline Symbol & Parameters & Value \\
\hline$F$ & Faraday's constant & $96487 \mathrm{C} / \mathrm{mol}$ \\
\hline$D_{c}$ & Diffusion coefficient of free $\mathrm{Ca}^{2+}$ in cytosol & $265 \mu \mathrm{m}^{2} / \mathrm{s}$ at $25^{\circ} \mathrm{C}$ \\
\hline$Z$ & Valence of $\mathrm{Ca}^{2+}$ & 2 \\
\hline$\left[\mathrm{Ca}^{2+}\right]_{\text {out }}$ & calcium concentration in extracellular region & $10^{-3} \mathrm{Moles}$ \\
\hline$T$ & Temperature in Kelvin $\left(25^{\circ} \mathrm{C}\right)$ & $298.15 \mathrm{Kelvin}$ \\
\hline$\sigma$ & Source Amplitude & $1 \mathrm{pA}$ \\
\hline$R$ & Gas constant & $8.314 \mathrm{~J} \mathrm{~mol}^{-1} \mathrm{~s}^{-1}$ \\
\hline$P_{\max }$ & Permeability constant & $5.4 \times 10^{-6} \mathrm{~m} / \mathrm{s}$ \\
\hline
\end{tabular}

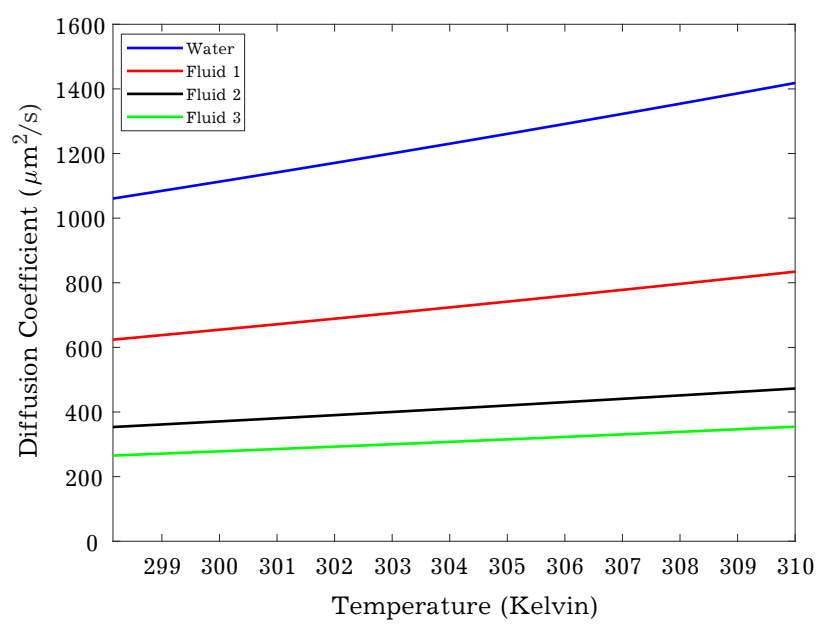

Fig. 2. Variation in diffusion coefficient of fluids which are more viscous in comparison with water. [Refer description of Fig. 1].

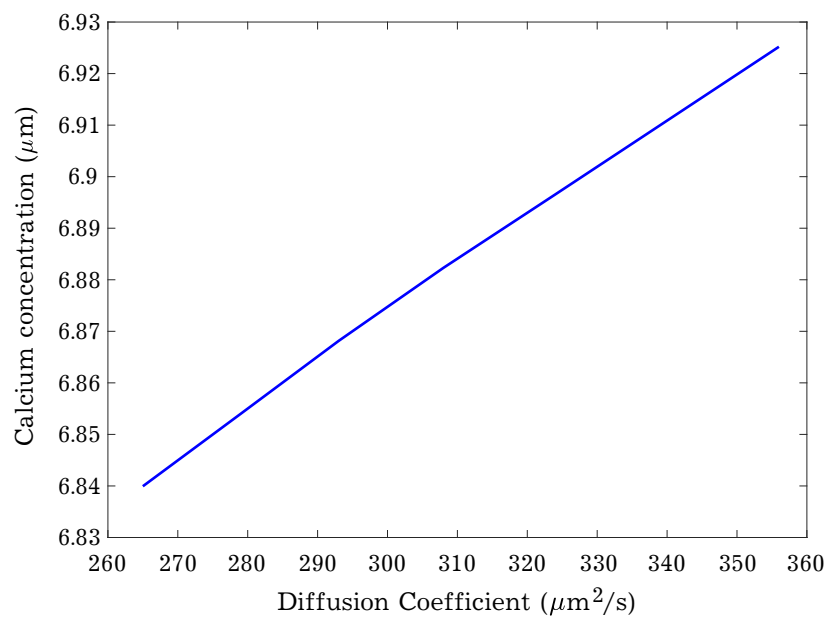

Fig. 3. Variation in calcium concentration due to variable diffusion coefficient. For source amplitude $\sigma=1 \mathrm{pA}$ and fixed radius $r=1 \mu \mathrm{m}$.

on cytosolic viscosity, the intracellular viscosity values obtained by different methods, in various kinds of cells, vary widely: from values close to the viscosity of water $\left(1 \mathrm{cP}\right.$ at $20^{\circ} \mathrm{C}$ and $0.75 \mathrm{cP}$ at $\left.37^{\circ} \mathrm{C}\right)$ to values which are up to ten times higher [21]. Referring Figure 2, we can understand the variation of diffusion coefficient w.r.t. temperature for different fluids with different viscosities. As temperature increases diffusion coefficient in each fluid increases.

Figure 3 shows a graph for calcium concentration vs diffusion coefficient. Here, variable diffusion coefficient of cytoplasm is considered. Cytoplasm is considered as fluid 3, which is four times more viscous than water. Calcium concentration increases as the diffusion coefficient increases. Variable diffusion coefficient is calculated with variable temperature. 


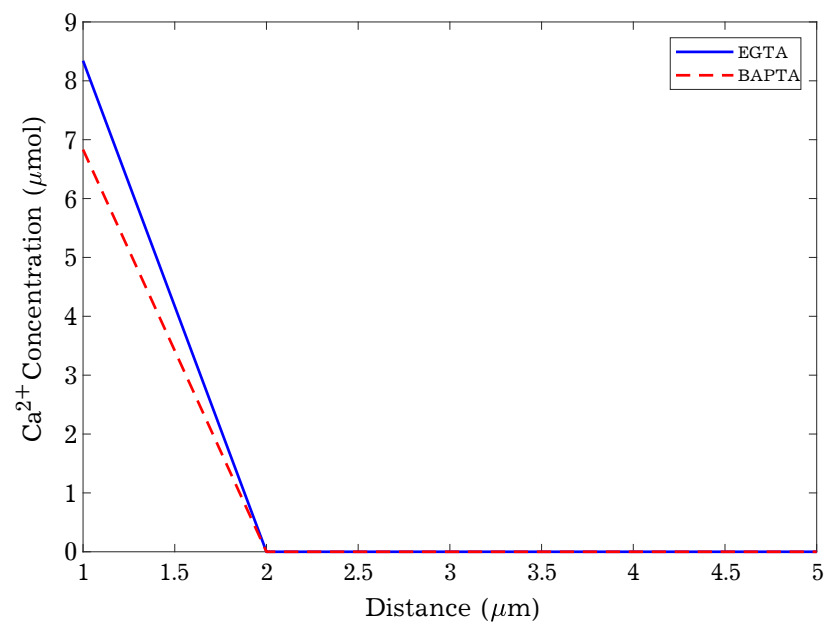

Fig. 4. Calcium concentration profile w.r.t. position, where $D_{c}=265 \mu \mathrm{m}^{2} / \mathrm{s}$ and $\sigma=1 \mathrm{pA}$.

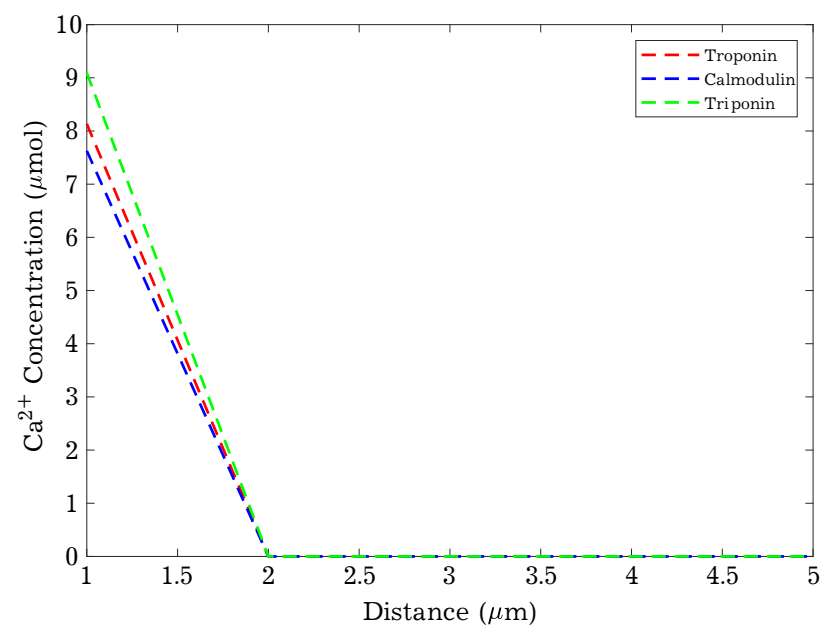

Fig. 5. Calcium concentration profile w.r.t. position for endogenous buffers, where $D_{\mathrm{c}}=265 \mu \mathrm{m}^{2} / \mathrm{s}$ and $\sigma=1 \mathrm{pA}$.

In study of the diffusion of calcium in neuronal cell, buffer plays an important role. The binding capacity of the buffer maintains the concentration of calcium in the intracellular process. Calcium concentration increased to a great extend based on the influx activity of gated channels. In such case, buffers are highly effective to reduce intracellular free-calcium concentration. In Figure 4, the steady-state calcium profile is plotted for two endogenous buffers EGTA and BAPTA corresponding to distance from the source. EGTA has lower association rate compared to BAPTA. Therefore, fall in calcium concentration for slow buffer [EGTA- blue line] is less sharp compared to the fast buffer [BAPTA-red line]. This is because the binding rate of fast buffer [BAPTA] is very high and causes the $\mathrm{Ca}^{2+}$ to fall more sharply as compared to that in the case of slow buffer [EGTA].

Figure 5 shows the profile of calcium concentration w.r.t. distance from the source for $D_{\mathrm{c}}=$ $265 \mu \mathrm{m}^{2} / \mathrm{s}$ and $\sigma=1 \mathrm{pA}$. Here, $D_{\mathrm{c}}$ is calculated for $25^{\circ} \mathrm{C}$ temperature using equation (14). For all standard values refer Table 2 behavior of endogenous buffers observed. We can see that the difference between the curves is not much, this is because there is little variation in the binding rate of different endogenous buffers.

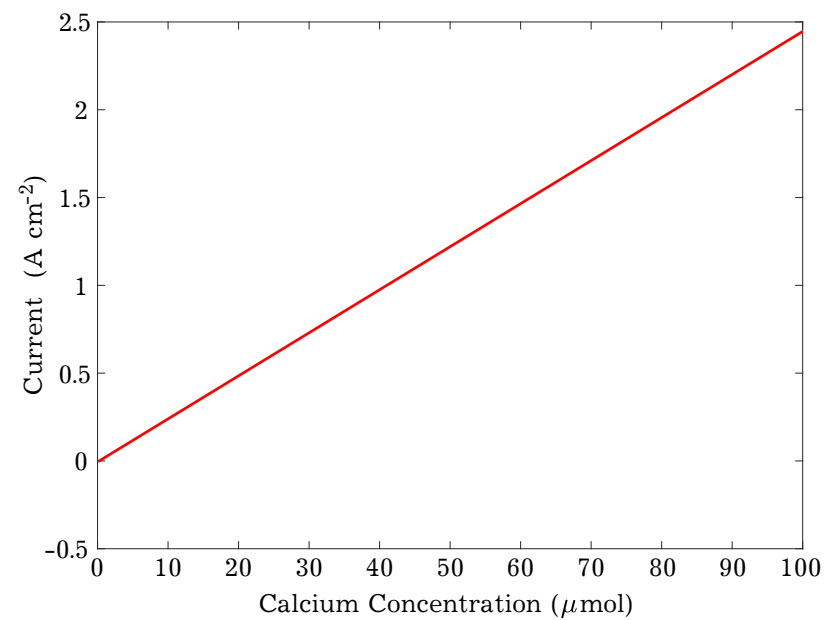

Fig. 6. Variation in current and calcium concentration where, $D_{\mathrm{c}}=265 \mu \mathrm{m}^{2} / \mathrm{s}$, membrane permeability constant is $P_{\max }=5.4 \times 10^{-6} \mathrm{~m} / \mathrm{s}$.

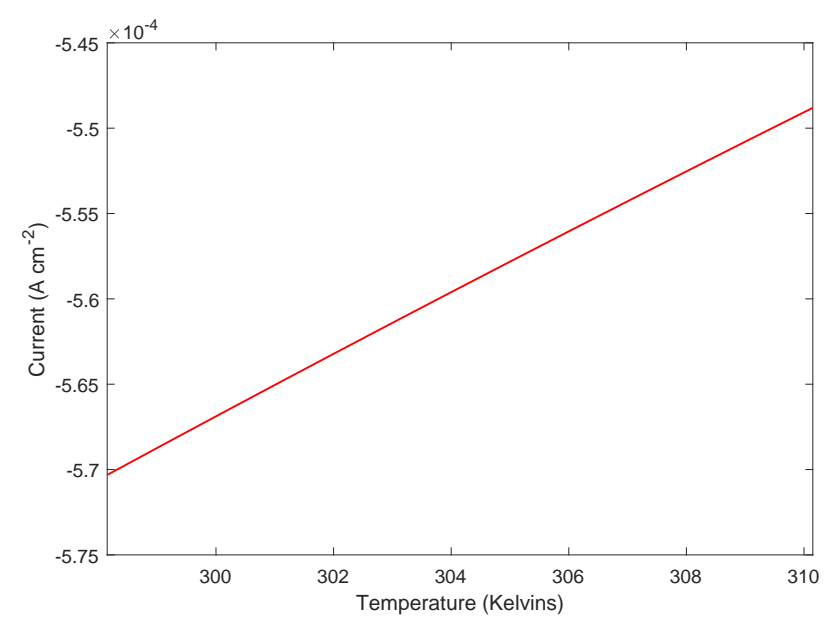

Fig. 7. Solution of GHK current equation for $\mathrm{Ca}^{2+}$. Current is plotted as a function of temperature with permeability constant $P_{\max }=5.4 \times 10^{-6} \mathrm{~m} / \mathrm{s}$. 


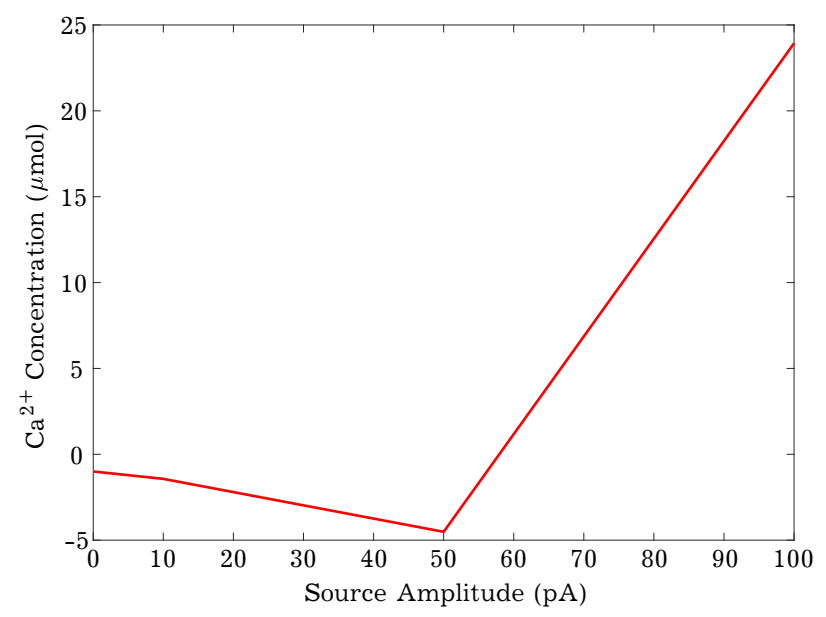

Fig. 8. $\mathrm{Ca}^{2+}$ concentration at fixed radius $r=$ $0.03 \mu \mathrm{m}$ is plotted as a function of source amplitude $\sigma$ using steady state excess buffer approximation for

$$
D_{\mathrm{c}}=265 \mu \mathrm{m}^{2} / \mathrm{s} \text {. }
$$

Corresponding to calculated diffusion coefficient $265 \mu \mathrm{m}^{2} / \mathrm{s}$ and membrane permeability $5.4 \times$ $10^{-6} \mathrm{~m} / \mathrm{s}$ in Figures $6-8$, we attempted to analyze the effect of the diffusion coefficient on calcium profile and current. Figure 6 gives a variation in current calculated calcium concentration. As calcium concentration increases cytosolic current also linearly increases. Figure 7 gives a graph between temperature and current. As the temperature is an important factor that affects cytosolic activities $[24,25]$, current with increasing temperature increases [measured in $\mathrm{pA}$ ]; which gives a linear graph. Figure 8 gives a graph between calcium concentration and source amplitude. The relationship between source amplitude \& calcium concentration is non-linear in between $\sigma=0$ to $50 \mathrm{pA}$ and it is linear between $\sigma=50$ to $100 \mathrm{pA}$.

\section{Conclusions}

Buffers play a unique role in forming calcium signals if relevant concentration gradients are present in the cell. Buffers regulate concentration formed by influx and calcium microdomain. Similarly, temperature and viscosity of cytosolic plasma play important role in the determination of the diffusion coefficient which is responsible for the diffusion of calcium. Many researchers worked on variation in viscosity in cytosolic plasma corresponding to temperature using various methods. However, the values of viscosity found very close to water [21]. Therefore, the current study based on this assumption which is novel up to our understanding is used to study the calcium signaling. The results of our model are quite in agreement with the biological facts and experimental results obtained by earlier research workers. Results for potential dependent diffusion of calcium are for under steady state are also meeting biological facts. Such models can be developed to generate information regarding concentration distributions in the cells and relationships among various parameters involved in the biological phenomena. Any abnormalities in influxes or potential due to any disease or environmental conditions can cause disturbances in calcium concentration profiles. The information obtained from these models can be of great use to biomedical scientists to understand the biological processes and to develop protocols for the detection and treatment of diseases. Similarly, it will help to understand biological facts based on the variation of viscosity, temperature and diffusion coefficient on calcium signaling.

\section{Acknowledgment}

The authors would like to thank Department of Mathematics, Dr. Babasaheb Ambedkar Marathwada University for availing infrastructure facility for this work.

[1] Augustine G. J., Santamaria F., Tanaka K. Local calcium signaling in neurons. Neuron. 40 (2), 331-346 (2003).

[2] Matthews E. A., Dietrich D. Buffer mobility and the regulation of neuronal calcium domains. Frontiers in Cellular Neuroscience. 9, 48 (2015).

[3] Bormann G., Brosens F., De Schutter E. Chapter 8: Modeling molecular diffusion. In: Bower J. M., Bolouri H. (eds.) Computational Methods in Molecular and Cellular Biology: from Genotype to Phenotype. MIT Press, Boston Reviews in the Neurosciences (2001). 
[4] Carnevale N. T. Modeling intracellular ion diffusion. Abstr. Soc. Neurosci. 15, 1143 (1989).

[5] Crank J. The mathematics of diffusion. Clarendon Press, Oxford, UK (1975).

[6] Naraghi M., Neher E. Linearized buffered $\mathrm{Ca}^{2+}$ diffusion in microdomains and its implications for calculation of $\mathrm{Ca}^{2+}$ at the mouth of a calcium channel. Journal of Neuroscience. 17 (18), 6961-6973 (1997).

[7] Nasi E., Tillotson D. The rate of diffusion of $\mathrm{Ca}^{2+}$ and $\mathrm{Ba}^{2+}$ in a nerve cell body. Biophysical Journal. 47 (5), 735-738 (1985).

[8] Smith G. D. Analytical steady-state solution to the rapid buffering approximation near an open $\mathrm{Ca}^{2+}$ channel. Biophysical Journal. 71 (6), 3064-3072 (1996).

[9] Fain G. L. Molecular and cellular physiology of neurons. Harvard Uni. press (1999).

[10] Sharma L. A Numerical Model to Study Excess Buffering Approximation near an Open $\mathrm{Ca}^{2+}$ Channel for an Unsteady State Case. Elixir Appl. Math. 73, 26214-26217 (2014).

[11] McHugh J. M., Kenyon J. L. An Excel-based model of $\mathrm{Ca}^{2+}$ diffusion and fura 2 measurements in a spherical cell. American Journal of Physiology-Cell Physiology. 286 (2), C342-C348 (2004).

[12] Neher E. Concentration profiles of intracellular $\mathrm{Ca}^{2+}$ in presense of diffusible cheltors. Exp. Brain Res. 14, 80-96 (1986).

[13] Sharma L. A Numerical Model to Study the Rapid Buffering Approximation near an Open $\mathrm{Ca}^{2+}$ Channel for an Unsteady State Case. International Journal of Physical and Mathematical Sciences. 8 (2), 445-449 (2014).

[14] Sharma L. A Numerical Model to Study Effect of Potential-Dependent Influx on Calcium Diffusion in Neuron Cells. Research \& Reviews: Journal of Neuroscience. 4 (1), 1-8 (2014).

[15] Rao S. S. The Finite Element Method in Engineering. Elsevier Sci. Technol. (2004).

[16] Shannon T. R., Wang F., Puglisi J., Weber C., Bers D. M. A mathematical treatment of integrated Ca dynamics within the ventricular myocyte. Biophysical Journal. 87 (5), P3351-P3371 (2004).

[17] Rao S. S. The finite element method in engineering. Butterworth-Heinemann (2017).

[18] Reddy J. N. An introduction to the finite element method. New York, McGraw-Hill (2004).

[19] Keener J. P., Sneyd J. Mathematical physiology. New York, Springer (1998).

[20] Luby-Phelps K. Cytoarchitecture and physical properties of cytoplasm: volume, viscosity, diffusion, intra cellular surface area. International Review of Cytology. 192, 189-221 (1999).

[21] Puchkov E. O. Intracellular viscosity: Methods of measurement and role in metabolism. Biochemistry (Moscow) Supplement Series A: Membrane and Cell Biology. 7 (4), 270-279 (2013).

[22] Viswanath D. S, Natarajan G. Data book on the viscosity of liquids. New York, Hemisphere Pub. Corp. (1989).

[23] Vogel H. Das Temperaturabhangigkeitsgesetz der Viskosität von Flüssigkeiten. Physikalische Zeitschrift. 22, 645-646 (1921).

[24] Tanimoto R., Hiraiwa T., Nakai Y., Shindo Y., Oka K., Hiroi N., Funahashi A. Detection of Temperature Difference in Neuronal Cells. Scientific Reports. 6, 22071 (2016).

[25] Van Hook M. J. Temperature effects on synaptic transmission and neuronal function in the visual thalamus. PloS one. 15 (4), e0232451 (2020).

[26] Bertram R., Smith G. D., Sherman A. Modeling Molelling study of the effects of overlapping $\mathrm{Ca}^{2+}$ microdomains on neurotransmitter release. Biophysical Journal. 76 (2), 735-750 (1999).

[27] Sherman A., Smith G. D., Dai L., Miura R. M. Asymptotic analysis of buffered calcium diffusion near a point source. SIAM Journal on Applied Mathematics. 61 (5), 1816-1838 (2001).

[28] Mantina M., Chamberlin A. C., Valero R., Cramer C. J., Truhlar D. G. Consistent van der Waals radii for the whole main group. Journal of Physical Chemistry A. 113 (19), 5806-5812 (2009). 


\title{
Дослідження профілю кальція в нейронних клітинах залежно від температури та стану за наявності притоку потенційно активного кальція
}

\author{
Патил Дж. В. ${ }^{1}$, Вазе А. Н. ${ }^{2}$, Шарма Л. ${ }^{2}$, Бачав А. ${ }^{3}$ \\ ${ }^{1}$ Кафедра математики, Васантрао Найк Махавідялая, Аурангабад, Індія \\ ${ }^{2}$ Кафедра інженерного курсу першого курсу, Інженерний коледж Пімпри Чінчвад, Пуна, Індія \\ ${ }^{3}$ Школа управління Навін Джиндал, Техаський університет, Даллас, США
}

Кальцій є важливим другим кур'єром передачі нервових імпульсів. Він надходить в клітини через керовані $\mathrm{Ca}^{2+}$ канали і регулює нейротрансмісію. Цей механізм контролюється за допомогою дифузії кальцію, буферного механізму та притоками кальцію в цитоплазму. Вивчення динаміки $\mathrm{Ca}^{2+}$ цікаве, оскільки концентрація $\mathrm{Ca}^{2+}$ демонструє дуже складну просторово-часову поведінку. Існує безліч засобів контролю концентрації $\mathrm{Ca}^{2+}$ в цитоплазмі; по-перше, він сильно буферизується (тобто зв'язується) великими білками, а по-друге, контроль здійснюється за допомогою змінного коефіцієнта дифузії. Коефіцієнт дифузії прямо пропорційний температурі та обернено пропорційний в'язкості. У цій роботі досліджено одновимірний випадок стаціонарного стану з граничними умовами для розуміння розподілу $\mathrm{Ca}^{2+}$ у нейронних клітинах, що включає дифузію кальцію, точкове джерело, надлишкове буферне наближення (НБН) та надходження кальцію через потік. Також вивчається залежність концентрації $\mathrm{Ca}^{2+}$ від різних значень коефіцієнта дифузії. Для отримання розв'язків застосовувався метод скінченних елементів (МСE).

Ключові слова: дифузія кальиію, змінний коефіціент дифузї̈, НБН, МСЕ. 